\title{
Assessment of qualitative indicators of drinking water and their influence on human health, as ecological safety factor of population
}

\author{
V.L. Bondarenko ${ }^{1}$, E.D. Khetsuriani ${ }^{2 *}$, A.I. Ilyasov ${ }^{3}$, and E.A. Semenova ${ }^{4}$ \\ ${ }^{1}$ Novocherkassk Engineering And Land Reclamation Institute Of Don State Agrarian University, \\ 111, Pushkinskaya str., Novocherkassk, 346428, Russia \\ ${ }^{2}$ M.I. Platov South-Russian State Technical University (Novocherkassk Polytechnic Institute), 132, \\ Prosvescheniya str., Novocherkassk, 346428, Russia \\ ${ }^{3}$ Director of the branch WTL (USA) in Asia, 7A, build. 2, Novatorov str., Moscow, 119421, Russia \\ ${ }^{4}$ North-Caucasus Federal University (Branch in Pyatigorsk), 56, 40-let Oktyabrya, Pyatigorsk, \\ 357500, Russia
}

\begin{abstract}
Based on the results of experimental studies of the cyanobacteria and toxins properties, produced by blue-green algae, was assessed the quality of drinking water according to organoleptic characteristics in the area of the Lower Don geosystem. Experimental data on the properties of cyanobacteria and toxins produced by blue-green algae are presented in this study. Based on the results of research at the pilot plant, the basics of drinking water purification technology in the water dipper from blue-green algae have been developed, which to some extent helps to increase the environmental safety of drinking water in urban systems and settlements.
\end{abstract}

\section{Introduction}

Quantitative and qualitative indicators of water resources are formed within the spatial boundaries of basin geosystems, where all types of economic activity related to the use of water resources are conducted.

At the present stage of social development of the global system "Nature-Society-Human" ten most important problems have formed, of which the first three problems - energy, water and food are the most important, it is impossible to solve the other seven problems, without solving these three. The problems of Energy, Water and Food are interlinked, where the Energy problem is dominant and plays a dominant role in all the ongoing processes both in the spatial limits of the Earth's biosphere $\left(\mathrm{W}_{\text {e.b. }}=10^{10} \mathrm{~km}^{3}\right)$, and within the local river basin geosystems, where quantitative and qualitative indicators of water resources in the form of surface and groundwater flow. Quantitative indicators of water flow in the global moisture circulation within the Earth's biosphere (in the amount of 575 thousand $\mathrm{km}^{3}$ ) are formed under the continuous influence of energy flows from the primary source - the Sun.

\footnotetext{
* Corresponding author: serdariaziev@gmail.com
} 
Studies have established [3-15] that qualitative indicators of water resources by $65-75 \%$ are formed in the water intake area of the basin geosystem under consideration, for example, the river basin. Don $\left(\mathrm{F}_{\mathrm{b} . \mathrm{g}} .=422\right.$ thousand $\left.\mathrm{km}^{2}\right)$, where the population of 15 constituent entities of the Russian Federation (13.5 million people) and three regions of Ukraine lives and almost all types of modern branches of economic activity are conducted. Wastewater discharges from industrial and processing enterprises, as well as public utilities, form qualitative indicators at water bodies by $30-35 \%$.

Based on what noted above, when solving the problem of ensuring environmental safety (ES) on water bodies, used in multi-purpose water supply systems of urban households and settlements, it is necessary to take into the account the objective reality in the formation of qualitative indicators of water resources within the considered basin geosystems. In a systematic consideration, the ES of a water body should be understood as its economic state (ES), which is formed within the spatial boundaries of the basin geosystem under the influence of natural processes of interconnection, interaction and interrelation (III) between the biotic and abiotic components and the economic activities of the living population. Therefore, it can be concluded, that the water body's ES determines its energy base relative to the living population, which uses the water body as a water source for a drinking water supply system.

Studies have established that up to $70 \%$ of all pollutants entering biota living organisms, including humans, are carried out by consuming food products containing water [2-9]. Consequently, in order to ensure ES as the dominant determining factor in the health of the living population within the basin geosystem under consideration, there is an urgent need to ensure acceptable ES in natural environments and objects of economic activity, which are pollution sources of surface and underground waters, the qualitative state of which is an indicator of ES of the basin geosystem.

Therefore, the purpose of the work was to assess the epidemic significance of indicators of microbial water pollution of the main sources of water supply in the Rostov region. Based on the goal, the main objective of the research was the sanitary-bacteriological characteristics of the water quality of the Tsimlyansk reservoir and the Lower Don, as well as drinking water of the cities of Azov and Tsimlyansk, whose population uses the above sources for domestic water supply. The emphasis in the sanitary-bacteriological assessment of water quality was given to the detection of pathogenic and potentially pathogenic microflora, as the most important indicators in the development of approaches to assessing microbial risk in various types of water usage.

\section{Materials and Methods}

The protection of surface and groundwater of water bodies within the spatial boundaries of the basin geosystem from the pollutants flow represents an environmental problem, and the solution of this problem largely affects the health of the living population. Thus, monitoring studies of the qualitative indicators of the natural aquatic environment (NAE) of the Lower Don, from the Tsimlyansk reservoir to its mouth, established a steady tendency for the accumulation and development of pathogenic microbes $[5,11,17]\left(\mathrm{W}_{1}\right)$, which cause intestinal infectious diseases $[2,35,10,16]\left(\mathrm{W}_{1}\right)$. Qualitative water indicators used in drinking water supply systems are determined by conducting a complete physico-chemical, sanitary-bacteriological and technological analysis of the water of the water body, used as a water source. An important aspect is the isolation of the most significant microorganisms present in the aquatic environment and capable to cause an acute intestinal infections (AII) among the population. 


\section{Results and Discussion}

In modern conditions, the health of the living population within the basin of the Lower Don, as evidenced by the results of studies determined by the influence of environmental factors. Among the most important factors characterizing the sanitary-epidemiological well-being is the provision the population with safe drinking water [2,30,31]. This factor is an urgent hygienic, scientific, technical and social problem due to the intense chemical and bacterial contamination of drinking water supply sources $[23,30,6,7]$, the use of outdated treatment schemes of water source, the low level of implementation of advanced water treatment technologies, and growing deterioration water supply networks [31, 23, 17, 27].

The basis of hygienic water quality requirements for drinking and domestic needs is the principle that puts in the spotlight those qualities on which human health depends.

The problem of maintaining water quality in the Rostov Region (RR), as a factor significantly affecting not only the infectious, but also the general morbidity of the population, is one of the highest priorities.

The studies were conducted in a pilot experimental plant using flowering Don water, selected from the river. Don in the place of Alexander's water intake in the Rostov region.

The object of the study is the properties of cyanobacteria and toxins produced by bluegreen algae, their effect on organoleptic indicators of water, as indicators of the epidemiological safety of public health and experimental studies on abatement technologies

To achieve this goal, the following tasks were identified and solved:

1. Study the effect of toxins released by blue-green algae on organoleptic water indicators and human health;

2. Conduct laboratory studies of cyanobacteria and toxins secreted by blue-green algae;

3. experimental studies on the technology for treating flowering Don water to ensure the environmental safety of drinking water and public health.

For water supply in Rostov-on-Don, Bataysk and Aksai, a surface source is used - the Don River, the water quality in which in the summer-autumn period of the year exceeds phytoplankton concentration more than 4 times the allowable standard for water sources suitable for use as sources of economic drinking water supply. Strict hygienic requirements are imposed on the quality of drinking water: the water must be safe in epidemiological and radiation terms, harmless in chemical composition and have favorable organoleptic properties. The massive development of microphytes in the waters of surface sources of water supply during periods of flowering creates significant difficulties in water treatment and significantly affects standardized indicators as "smell" and "taste".

An analysis of the literature data showed that some types of microalgae, as a result of their vital functions, as well as during decompositioning and obsoleting, dying with actinomycetes, are producers of "smelling" substances, such microalgae can include species Oscillatoria agardhii, Aphanizomenon flos-aqua, Anabaena flos-aqua, Melosira granulate, Nodularie and others. As a result of the development of various microalgae, the following smells are most often found: putrid-earthy, putrefactive, earthy-putrefactive, putrefactivetinnitus, grassy putrid, earthy, dung, rotten-muddy, fishy. Volatile natural organic substances such as geosmin, 2-methylisobornoleol (MIB), etc., emitted by microalgae and actinomycetes, determine these smells. These indicators were determined in water using chromato-mass spectrometric analysis.

In order to study the quality of the upstream water source and determine the possible source of algae development, in September 2017, we organized an experimental trip up the Don River from the Aleksandrovsky water intake to the inlet of the Manych River with sampling at 13 points. As a result of the analysis of the water taken from the Don River, Aksai River, Manych River, high concentrations of microalgae were determined in all 
water samples, on average $70,000 \mathrm{cl} / \mathrm{ml}$, with the predominance of the species Aphanizomenon flos-aqua, except for the water sample from the Manych River, where the temperature water, turbidity, phosphorus, COD and the concentration of microalgae were significantly lower than in all other water samples.

Drinking water should have good organoleptic properties, i.e. be transparent, colorless, unpainted, without taste and smells, have a refreshing temperature and do not contain visible impurities. The optimum drinking water temperature for human physiological needs is $8-15 \mathrm{C}$, it has a pleasant refreshing effect, better quenches thirst, is absorbed faster, stimulates the secretory and motor activity of gastrointestinal waste. A water temperature of $25 \mathrm{C}$ does not quench thirst; a temperature of 25-35 o $\mathrm{C}$ is unpleasant and causes a gag reflex.

The hygienic significance of smells and tastes of water is that when their intensity is above 2 points, water consumption is limited; artificial smells and tastes can be indicators of water pollution by wastewater; natural smells and tastes above 2 points indicate the presence in the water of biologically active substances secreted by blue-green algae.

Toxins secreted by blue-green algae, entering the human body, cause acute poisoning with neurological symptoms, various dermatitis, gastroenteritis, and even lead to liver necrosis $[23,31,30]$.

Only three types of data on the effect on the heart were revealed: Microcystis, Anabaena and Nodularia. Symptoms of poisoning were manifested in a weak and rare, or vice versa, increased pulse, pericardial or endocardial hemorrhages.

A person is less sensitive to the effects of toxic blue-green algae, in addition, for poisoning with a fatal outcome, a person weighing $70 \mathrm{~kg}$ needs to drink 2.5 liters of water saturated with algae. The effect of algae on humans can also be indirect - through fish, animals and plants.

With algae intoxication, we distinguish gastrointestinal, respiratory, skin effects, which are expressed in the form of conjunctivitis and allergies. It has been established that bluegreen algae release phenols into the environment, which also cause skin lesions $[2,4,5]$.

Every year, more than 600 thousand people use drinking water from centralized domestic water supply systems that do not meet hygienic standards for the content of chemicals. The data of epidemiological studies show that drinking water of increased mineralization contributes to the development of diseases such as urolithiasis, hypertension, metabolic polyarthritis.

A respiratory system disease caused by exposure to some blue-green algae, according to the descriptions of Dr. Heise $(1949,1951)$, who observed such cases in rural areas near the lakes Miskego, Kinzis and North (Wisconsin, USA), blooming with oscillatoria, is allergic in nature, meaning that patients (men and women) experienced complete nasal blockage, itchy eyes or swollen eyelids, mild suffocation (asthma). Some scientists (D.S.

Samoilovich, D.K. Zabolotny, E.N. Pavlovsky and others) associate the modern mass distribution of blue-green algae in fresh water bodies and with other phenomena that are extremely harmful to humans, for example, with the spread of cholera epidemics or seasonal spread of poliomyelitis.

The peak of algae development in the Don river water source occurs in the AugustSeptember, it is during these periods that the water acquires a specific smell, the intensity of which can exceed 2 points, the smell is defined as "grassy putrid", "putrefactive".

Determining the exact amount of toxins in each sample of microalgae requires the use of toxin standards, which are absent at the beginning of the study, therefore, so, a strict quantitative analysis of the toxin content in the samples was not carried out. Thus, the analytical equipment and sample techniques used during the work detected and identified toxins produced by cyanoprokaryotes. In the waters of the Lower Don during the period of decline in the activity of microalgae, anatoxin-a microcystin-RR was identified 
approximately in a concentration hazardous to health (at a level of more than $0.01 \mu \mathrm{g} / 1$ ). This concentration is common in areas where toxic "water blooms" are observed. [1,2,4,5,]

For the first time, we conducted a series of experiments on the removal of blue-green algae on filters with a ruff loading. A pilot plant was made.

The studies were conducted on flowering Don water, which was brought from the Don River and filled the experimental pool.

In order to obtain a comparative characteristic of the operating efficiency of the technologies under study, experiments were carried out in two stages: the first was filtration only on a brushed load and the second was with the addition of the UNIKOS coagulant, KMP-30 coagulant and oxychloride $\mathrm{Al}(\mathrm{B})$ coagulant. Calibrated instruments were used to process the parameters of the studied water: a photoelectrocolorimeter (PEC), a $\mathrm{pH}$ meter, and an apparatus for determining the salinity of liquids.

Analysis of water showed the presence of the volatile organic substance "geosmin", which is a producer of a number of microalgae, in an amount corresponding to the lower limit of the threshold for influence on the organoleptic indicator "smell". In this case, the concentration of microalgae in the selected water sample was $5160 \mathrm{cl} / \mathrm{ml}$, of which the concentration of Aphanizomenon flos-aqua microalgae was $800 \mathrm{cl} / \mathrm{ml}$, the laboratory identified the smell as "mossy" or "grassy putrid" with an intensity of $0 / 1$ point. During this period, the concentrations of the products of their vital functions, geosmin and MIB, were significantly higher. The amount of microcystis in the water of the Don River is quite large. Among all algae, microcystis takes the second place in the number of cells and the first place in biomass. The study of this problem in the Don requires special attention.

\section{Summary}

It was found that using only ruff loading without coagulants removes more than $50 \%$ of the algae, and together with the coagulant - more than $90 \%$. Under the influence of mineral coagulants, which are also used to clarify and purify water that goes into the water supply, algae irreversibly stick together into lumps and linger on ruffs. The smell after regenerations is also removed, since all impurities are quickly collected by the bubble oxidant and removed together with the accumulated foam, without stagnating.

Ensuring acceptable water quality in the Lower Don, as a factor of environmental safety, significantly affecting not only the infectious, but also the overall morbidity of the population, is one of the priorities.

In the Don River, the water quality during the summer-autumn season the phytoplankton concentration exceeds more than 4 times the allowable standard for water sources suitable for a use as sources of drinking water supply, organoleptic indicators of water are extremely dangerous for the epidemic safety of public health.

When assessing the organoleptic indicators of drinking water (color, turbidity, taste, etc.), especially in the summer months of June-August, it is useful to determine the amount of microcystis and toxins released by blue-green algae, which can serve as a basis for calculating the epidemic safety of water use, as a factor for ensuring environmental safety of population.

Application of the developed technology to purify flowering Don water from organoleptic indicators, to eliminate the need for primary disinfection of water with chlorine or to reduce the consumption of chlorine to a minimum; It will give stability to the water treatment character and significantly reduce the cost of water treatment from bluegreen algae and also will ensure the sanitary and epidemiological safety of drinking water and public health. 


\section{References}

1. V.V. Aleshnya, P.V. Zhuravlev, O.P. Panasovets, Study under experimental conditions of the action of pesticides on microorganisms that characterize the sanitary and epidemiological safety of a reservoir, Hygiene and Sanitation, 95(8), 785 -789 (2016)

2. V.V. Aleshnya, P.V. Zhuravlev, S.V. Golovina et al., The value of indicator microorganisms in assessing microbial risk in the occurrence of an epidemic hazard in drinking water use, Hygiene and Sanitation, 2, 23-26. (2008)

3. E.D. Khetsuriani, L.N. Fesenko, I.A. Lapina, T.E. Khetsuriani, Energy-saving technologies to improve the environmental safety of water bodies, Materials of the $\mathrm{X}$ International Scientific and Practical Conference: "Prospects for the development of scientific and technical cooperation Member States of the Eurasian Economic Union, Astrakhan, 110-113 (2016),

4. P.V. Zhuravlev, V.V. Aleshnya, O.P. Panasovets, G.V. Aidinov, M.M. Shvager, T.V. Mitrofanova, B.Kh. Dzhanseyidov, G.A. Martynov, E.I. Derevyakina, Sanitary and bacteriological characteristics of the Lower Don ox, Hygiene and sanitation, 4, 28 31, (2012)

5. P.V. Zhuravlev, V.V. Aleshnya, S.V. Golovina, O.P. Panasovets, A.E. Nedachin, Yu.G. Talaeva, T.Z. Artyomova, E.K. Gipp, N.N. Butorina, A.V. Zagainova, Monitoring of bacterial contamination of water bodies in the Rostov Region, Hygiene and sanitation, 5, 33 - 35 (2010)

6. V.L. Bondarenko, A.B. Ylyasov, E.D. Khetsuriani, Scientific and methodological foundations of natural and technical systems in the use of water resources: territories of geosystem basins (Monograph, Novocherkassk, SRSPU (NPI), 2019)

7. V.L. Bondarenko, E.A. Semenova, A.V. Aliferov, O.V. Klimenko, Natural-technical systems in the use of water resources: territories of basin geosystems (Monograph, Novocherkassk, SRSPU (NPI), 2016)

8. V.A. Volosukhin, V.L. Bondarenko, Fundamentals of the methodology of system analysis of natural-technical systems for the use of water resources, Bulletin "Use and Protection of Natural Resources in Russia", 5, 15-24 (2015)

9. A.M. Chernyaev, River basins (Moscow. Agroecology, 1999)

10. Ged R. Davis, Energy for Planet Earth, In the World of Science, 11, 7-16 (1990)

11. P. Saling, A. Kicherer, B. Dittrich-Kramer, R. Wittlinger, W. Zombik, I. Schmidt, W. Schrott and S. Schmidt, Life Cycle Management. Eco-efficiency Analysis by BASF: The Method (Germany, BASF, 2002)

12. P. Saling, R. Hofer (ed), Metrics for Sustainability as part of RSC Green Chemistry No. 4, Sustainable Solutions for Modern Economies Edited by Rainer Höfer, The Royal Society of Chemistry, "Green Chemistry Series" edited by the Royal Society of Chemistry Series Editors: J. Clark, University of York; G. Kraus, Iowa State University, 25-37 (2009),

13. E.D. Khetsuriani, L.N. Fesenko, V.P. Kostyukov, T.E. Khetsuriani, Obtaining a regression equation and evaluating their adequacy for analyzing field studies, Obtaining a regression equation and evaluating their adequacy for analyzing field data Research, Norwegian Journal of the Development of International Science, 9(2g), 69-72 (2017)

14. D. Barnes, F. Galgani, R. Thompson, M. Barlaz, The accumulation and fragmentation of plastic waste in global conditions, Phil. Transaction R. Soc. B, 364, 1985-98 (2009) 
15. M.J. Behrenfeld, E. Boss, Beam attenuation and chlorophyll concentration as alternative optical indicators of phytoplankton biomass, J. Mar. Res., 64, 431-51 (2006)

16. M.J. Berenfeld, P.G. Falkowski, The rate of photosynthesis obtained from satellite concentration of chlorophyll, Limnol, Oceanogr, 42, 1-20 (1997)

17. M. Cole et al., Microplastic Ingestion, Zooplankton Environ, Sci. Technol, 47, 664655 (2013)

18. M. Dellnitz, G. Froyland, C. Horenkamp, K. Padberg-Gehle, Sen Gupta A., Seasonal variability of subpolar cycles in the Southern Ocean: a numerical study based on transport operators Non-linear process, Geophys, 16, 655-64 (2009)

19. G. Froyland, K. Padberg, M.H. England, Treguier A-M, Detection of coherent oceanic structures using transmission operators Phys, Rev. Lett, 98, 224503 (2007)

20. M.R. Gregory, Environmental effects of plastic debris in marine conditions entanglement, swallowing, strangulation, suspension, hitchhiking and alien intrusions, Phil. Transaction R. Soc. B., 364, 2013-25 (2009)

21. Lebreton L C-M, S.D. Greer, J.C. Borrero, Numerical simulation of floating debris in the oceans, March. Pollut. Bull, 64, 653-61 (2012)

22. R.C. Thompson, C.J. Moore, vom Saal F.S. and S.H. Swan, Plastics, the environment and human health: current consensus and future trends, Phil. Transaction R. Soc. B, 364, 2153-66 (2009)

23. T.L. Delworth et al., GFDL CM2 Models with Global Climate Connectivity, I. Formulation and Simulation Characteristics, 19, 643-74 (2006)

24. A. Gnanadesikan et al., Global climate models GFDL CM2, II, Basic Ocean Modeling, 19, 675-9725 (2006)

25. R.J. Haarsma, F. Selten, Anthropogenic changes in Walker circulation and their influence on the wave structure of extratropical planets in the Northern Hemisphere Klim, Dyn., 39, 1781-99 (2012)

26. R.J. Haarsma, F. Selten, Van Oldenborg G.J., Anthropogenic changes in the structure of the thermal and zonal flow over Western Europe and the Eastern North Atlantic in the models CMIP3 and CMIP5, Clim. Dean, 41, 2577-88 (2013)

27. Z. Babiński, Modern processes of the lower Cretan Vistula (geographical work), Wroclaw-Warsaw-Krakow, 157, 172 (1992)

28. G.P. Williams, M.G. Wolman, Effect of downstream dams on alluvial rivers, U.S. Geological Survey, 1286, 83. (1984)

29. G.G. Onishchenko, Influence of the state of the environment on public health. Unresolved problems and tasks, Hygiene and sanitation, 1, 3-10 (2003)

30. D.J. Dawson, D.P. Sartory, Microbiological safety of water, Brit. Med. Bull., 56(1), 74 -83. (2000)

31. P. Puyment, A. Berte, M. Prevost, B. Menard, B. Barbeau, Occurence of pathogenic microorganisms in the Suit-Lawrence River (Canada) and comparison of health risks for population of using it as their sourse of drinking water, Can. J. Microbiol, 6, $565-$ 576 (2000) 